\title{
PENGARUH KEPUASAN PASIEN PADA KUALITAS LAYANAN \\ RAWAT INAP TERHADAP NIAT DISCHARGE AGAINST MEDICAL ADVICE (DAMA) (Studi di Rumah Sakit Umum Daerah Pare Kabupaten Kediri)
}

\author{
Gandung Satriyono ${ }^{1}$ \\ Desi Kristanti ${ }^{2}$ \\ Fakultas Ekonomi Universitas Kadiri \\ gandungsatriyono@unik-kediri.ac.id; desikristanti@unik-kediri.ac.id
}

\begin{abstract}
The purpose of this study was to analyze patient satisfaction on the quality of inpatient services to DAMA (Discharge Against Medical Advice) intentions in the Pare District General Hospital of Kediri Regency. The results of the analysis of physician interaction quality data obtained significance values $(\mathrm{P}=0.018<\alpha=0.05)$, with the physician attitude indicator of significance value $(\mathrm{P}=0.694>\alpha=0.05)$; indicator of physician behavior $(\mathrm{P}=0.002<\alpha=0.05)$; indicator of physician expertise $(\mathrm{P}=0.027<\alpha=0.05)$. Thus the quality of the doctor's interaction influences the patient's intention to go home. The results of data analysis on the quality of nurse interaction $(\mathrm{P}=0.040<\alpha=0.05)$ with indicators of nurse attitudes $(\mathrm{P}=0.179>\alpha=0.05)$, indicators of nurse behavior $(\mathrm{P}=0.023<\alpha=0.05)$, indicators of expertise nurses $(\mathrm{P}=0.034<\alpha=0.05$. Thus the quality of the interaction of nurses affects the intention of the patient to go home. The results of the influence of physical environmental quality on the patient's intention to go home forced $(\mathrm{P}=$ $0.177>\alpha=0.05)$, thus the quality The environment does not affect the intention of the patient to go home forced.The results of the effect of the quality of the results on the patient's intention to go home forcibly $(\mathrm{P}=0.266>\alpha=0.05)$ Thus the quality of the results does not affect the patient's intention to go home.
\end{abstract}

Keyword : Quality of interaction; physical quality; quality of results; DAMA intention

\begin{abstract}
Abstrak
Tujuan Penelitian ini adalah menganalisis kepuasan pasien pada kualitas layanan rawat inap terhadap niat DAMA (Discharge Against Medical Advice) di Rumah Sakit Umum Daerah Pare Kabupaten Kediri. Hasil analisis data kualitas interaksi dokter diperoleh nilai signifikansi ( $\mathrm{P}=$ $0,018<\alpha=0,05)$, dengan indikator sikap dokter nilai signifikansi $(\mathrm{P}=0,694>\alpha=0,05)$; indikator perilaku dokter $(\mathrm{P}=0,002<\alpha=0,05)$; indikator keahlian dokter $(\mathrm{P}=0,027<\alpha=0,05)$. Dengan demikian kualitas interaksi dokter berpengaruh terhadap niat pasien pulang paksa. Hasil analisis data kualitas interaksi perawat $(\mathrm{P}=0,040<\alpha=0,05)$ dengan indikator sikap perawat $(\mathrm{P}=0,179$ $>\alpha=0,05)$, indikator perilaku perawat $(\mathrm{P}=0,023<\alpha=0,05)$, indikator keahlian perawat $(\mathrm{P}=$ $0,034<\alpha=0,05$. Dengan demikian kualitas interaksi perawat berpengaruh terhadap niat pasien pulang paksa. Hasil pengaruh kualitas lingkungan fisik terhadap niat pasien untuk pulang paksa $(\mathrm{P}=0,177>\alpha=0,05)$, dengan demikian kualitas lingkungan tidak berpengaruh terhadap niat pasien untuk pulang paksa. Hasil pengaruh kualitas hasil terhadap niat pasien untuk pulang paksa $(\mathrm{P}=0,266>\alpha=0,05)$. Dengan demikian kualitas hasil tidak berpengaruh terhadap niat pasien pulang paksa.
\end{abstract}

Kata kunci : Kualitas interaksi; kualitas fisik; kualitas hasil; niat DAMA 


\section{PENDAHULUAN}

Rumah sakit merupakan salah satu instansi pelayanan kesehatan yang memiliki peran dalam mendukung meningkatnya derajat kesehatan masyarakat. Sebagai tempat berobat, rumah sakut perlu memberikan pelayanan berkualitas yang sesuai dengan kebutuhan pasien dan sesuai dengan Standar Operasional Prosedur agar pasien puas terhadap pelayanan rumah sakit.

Berdasarkan WHO (World Health Organization), rumah sakit merupakan bagian integral dari suatu organisasi sosial dan kesehatan dengan fungsi menyedikan pelayanan paripurna (komprehensif), penyembuhan penyakit (kuratif) dan pencegahan penyakit (preventif) kepada masyarakat. Selanjutnya Undang-Undang No. 44 tahun 2009 tentang rumah sakit menyatakan bahwa yang dimaksud dengan rumah sakit adalah institusi pelayanan kesehatan yang menyelenggarakan pelayanan kesehatan perorangan seara paripurna yang menyediakan pelayanan rawat inap, rawat jalan dan gawat darurat.

DAMA (Discharge Against Medical Advice) dikenal sebagai fanomena dimana pasien meninggalkan rumah sakit tanpa berdasarkan saran medis (Lekas et al., 2015). DAMA terjadi ketika pasien memutuskan untuk meninggalkan rumah sakit sebelum dokter yang merawat telah merekomendasikan untuk pulang.

RSUD (Rumah Sakit Umum Daerah) Pare merupakan salah satu rumah sakit yang ada di Kabupaten Kediri. Dari data diperoleh informasi bahwa kejadian DAMA pasien banyak terjadi di RSUD Pare. Berdasarkan hasil penelitian meta-analisis tersebut dijelaskan bahwa ketidak puasan pasien, masalah keluarga dan individu, persepsi pasien terhadap kesejahteraan, ketidakpuasan terhadap pengobatan yang diperoleh, rendahnya status ekonomi, peralatan yang kurang layak, kurangnya pelayanan medis dan perawatan merupakan faktor yang secara signifikansi menyebabkan DAMA (Alfandre, 2009; Scaborn \& Osmun, 2004; Macrohon, 2012). Berdasarkan penjelasan tersebut, masalah yang diangkat dalam peneltiian ini adalah tingginya kejadian DAMA di RSUD Pare Kabupaten Kediri pada tahun 2018. Penelitian ini dilakukan untuk melihat pengaruh kepuasan pasien pada kualitas layanan rawat inap terhadap niat melakukan DAMA di Rumah Sakit Umum Daerah Pare Kabupaten Kediri. 


\section{Rumusan Masalah}

Rumusan masalah dalam penelitian ini adalah apakah terdapat pengaruh antara kepuasan pasien pada kualitas layanan rawat inap terhadap niat DAMA (Discharge Against Medical Advice) di Rumah Sakit Umum Daerah Pare Kabupaten Kediri.

\section{Tujuan Penelitian}

Menganalisis kepuasan pasien pada kualitas layanan rawat inap terhadap niat DAMA (Discharge Against Medical Advice) di Rumah Sakit Umum Daerah Pare Kabupaten Kediri.

\section{TINJAUAN PUSTAKA}

\section{Penelitian Terdahulu}

Penelitian terdahulu yang dilakukan terkait dengan DAMA (Discharge Against Medical Advice) adalah penelitian yang dilakukan oleh Mohseni et al. (2015) yang berjudul "rate and causes of discharge against medical advice in Iranian hosputals: a systematic review and meta-analysis" (Nilai dan penyebab pulang paksa di rumah sakit Iran : sebuah tinjauan sistematis dan meta analisis). Namun penelitian tersebut berbeda dengan penelitian yang akan dilakukan.

1. Judul penelitian sekarang yaitu pengaruh kepuasan pasien pada kualitas layanan raway inap terhadap niat DAMA (Discharge Against Medical Advice) (Studi di Rumah Sakit Umum Daerah Pare Kabupaten Kediri).

2. Waktu penelitian terdahulu 2015, penelitian sekarang pada tahun 2018 .

3. Metode yang digunakan dalam penelitian dahulu adalah meta analisis atau studi literatur menggunakan CMA (Comprehensive Meta-Analysis). Sedangkan pada penelitian ini dilakukan dengan analisis uji pengaruh/ regresi linier. Dengan demikian pengaruh antara variabel bebas dan terikat dapat dibuktikan secara ilmiah menggunakan aplikasi SPSS.

\section{Konsep Persepsi pada Kualitas Layanan.}

Brady dan Cronin (2001) menggambarkan masing-masing dari tiga kualitas itu dalam tiga aspek yang langsung mengukur masing-masing kualitas yaitu :

1. Kualitas interaksi yaitu kualitas yang berhubungan erat dengan bagaimana proses layanan itu disampaikan yaitu dilihat dari proses interaksi staf penyedia layanan terhadap pelanggannya (Gronroos, 2000). Dan proses interaksi tersebut dapat dilihat 
dari bagaimana cara staf bersikap, berperilaku terhadap pelanggannya serta keahlian yang mereka miliki. Kualitas interaksi digambarkan dalam tiga subdimensi yaitu :

a. Sikap yaitu kepribadian yang dimiliki oleh staf yang menunjukkan keramahan terhadap pelanggan. Contohnya, sikap dan kepribadian dari staf di pelayanan kesehatan sangat memperngaruhi pasien, staf disana sangat ramah.

b. Perilaku di sini dimaksudkan dengan sifat yang baik dari staf serta kemauan untuk melayani. Contohnya ketika ada pasien yang membuthkan bantuan, staf di pelayanan kesehatan langsung berempati menawarkan bantuan kepada pasien tersebut.

c. Keahlian yaitu kemampuan staf dalam melaksanakan pekerjaannya. Contohnya, staf di pelayanan kesehatan tahu akan pekerjaannya dan memiliki pengetahuan yang bagus serta keahlian dalam memberikan pertolongan medis kepada pasien dengan baik.

2. Kualitas lingkungan fisik menurut Gronroos (2000) merupakan kualitas yang ada di dalam lingkungan dimana proses pelayanan itu terjadi. Kualitas lingkungan fisik digambarkan ke dalam tiga subdimensi antara lain :

a. Kondisi lingkungan yaitu suatu kondisi yang dapat memberikan kenyamanan yang berkenaan dengan aspek nonvisual. Contohnya, dari jauh meja di tempat duduk pelanggan terlihat bersih tertapi begitu tangan diletakkan di atas meja, ternyata permukaan meja itu masih lengket.

b. Desain yaitu berhubungan dengan tata letak atau arsitktur ruangan.

c. Faktor sosial yaitu jumlah dan tipe pelanggan lainnya yang berada dalam lingkungan pelayanan, seperti tentang perilaku mereka. Contohnya, tangisan bayi seorang pelanggan sangat mengganggu pelanggan lainnya.

3. Kualitas hasil yaitu apa yang pelanggan dapatkan ketika proses produksi servis dan interaksi-nteraksi antar pelanggan dengan penyedia layanan selesai (Gronroos, 2000). Kualitas hasil digambarkan ke dalam tiga subdimensi abtara laun :

a. Waktu tunggu yaitu waktu yang pelanggan gunakan untuk menunggu kualitas yang didapatkan. Contohnya, untuk menunggu pelayanan seorang pasien, para pelanggan harus menunggu 15 menit. 
b. Bentuk nyata yaitu segala sesuatu yang berwujud. Contoh, kualitas hasil yang ada di pelayanan kesehatan sangat mengesankan, pelayanan yang diberikan sangat berkualitas dengan adanya dokter yang terampil.

c. Valensi yaitu ukuran tentang pengalaman yang didapat bisa baik ataupun jelek. Contohnya, ketika meninggalkan pelayanan kesehatan, para pelanggan memiliki pengalaman yang baik karena para staf di klinik atau rumah sakit memberikan pelayanan yang berkesan.

\section{DAMA (Discharge Against Medical Advice)}

DAMA (Discharge Against Medical Advice) terjadi ketika pasien memutuskan untuk meninggalkan rumah sakit sebelum dokter yang merawat menyarankan untuk pulang. Di Amerika Serikat, setiap tahun, 1-2\% dari semua kepulangan pasien di rumah sakit (kurang lebih 500.000 pasien) adalah pulan paksa (Glasgow et al., 2010; Ibrahim, 2007). Dibandingkan dengan kepulangan yang direncanakan, DAMA dihubungkan dengan merusak kesehatan dan hasil pemanfaatan pelayanan kesehatan termasuk rendahnya tingkat kedatangan janji tindak lanjut dari dokter dan tingginya pendaftaran kembali, kematian dan kejadian DAMA berikutnya (Baptist et al., 2007; Glasgow et al., 2010; Southern et al., 2012). Umur muda, jenis kelamin dan status ekonomi rendah, tidak memiliki asuransi kesehatan merupakan prediktor terjadinya DAMA (Alfandre, 2009; Glasgow et al., 2010).

Selain itu, salah satu alasan yang dapat menyebabkan DAMA di rumah sakit yang berada di negara berkembanga adalah kualitas pelayanan. Sebagai hasil penelitian yang dilakukan di Iran menunjukkan bahwa alasan utama yang berkaitan dengan terjadinya DAMA disebabkan oleh hubungan dalam rumah sakit (seperti kurangnya perhatian dari para dokter dan pasien, perilaku yang tidak pantas dari staf rumah sakit, peralatan dan lingkungan yang kurang baik). Dengan demikian, pemberian perhatian yang lebih pada pengembangan kualitas pelayanan yang diberikan kepada pasien perlu dilakukan.

Meskipun proses yang spesifik yang berkontribusi terhadap DAMA belum dapat didefinisikan dengan baik, peneliti dapat menghasilkan asumsi bahwa interaksi pasien dan dokter terdiri dari enam tahap yaitu (Lekas, 2016):

1) Pasien memberitahu staf bahwa dia ingin meninggalkan rumah sakit.

2) Dokter menyadari bahwa pasien menginginkan tidak datang pada perawatan yang telah dijanjikan. 
3) Dokter mencoba untuk mengumpulkan informasi tentang bagaimana pasien ingin pergi dan menyampaikan agar pasien tetap tinggal.

4) Pasien tidak berubah pikiran untuk meninggalkan rumah sakit.

5) Berdasarkan diskusi pasien dan dokter berakhir dengan dokter menyetujui tanpa bantahan keinginan pasien untuk pergi.

6) Dokter mengkonfirmasi kepulangan sebagai DAMA dengan mendokumentasikan interaksi dan penolakan informasi dari rawat inap di rekam medis dan meminta pasien untuk menandatangani formulir DAMA.

\section{Kerangka Operasional}

Populasi : seluruh pasien rawat inap di RSUD Pare Kabupaten Kediri yang melakukan DAMA

Teknik sampling : Stratified Random Sampling

Sampel : Pasien rawat inap yang pulang paksa di RSUD Pare Kabupaten Kediri yang terpilih menjadi sampel setelah pengacakan.

Data faktor kepuasan pasien pada kualitas layanan rawat inap :

1. Kualitas interaksi dokter dan perawat:

a. Sikap

b. Perilaku

c. Keahlian

2. Kualitas Lingkungan Fisik :

a. Kondisi ruangan

b. Desain ruangan

3. Kualitas hasil :

a. Kesan

Didapatkan melalui kuesioner

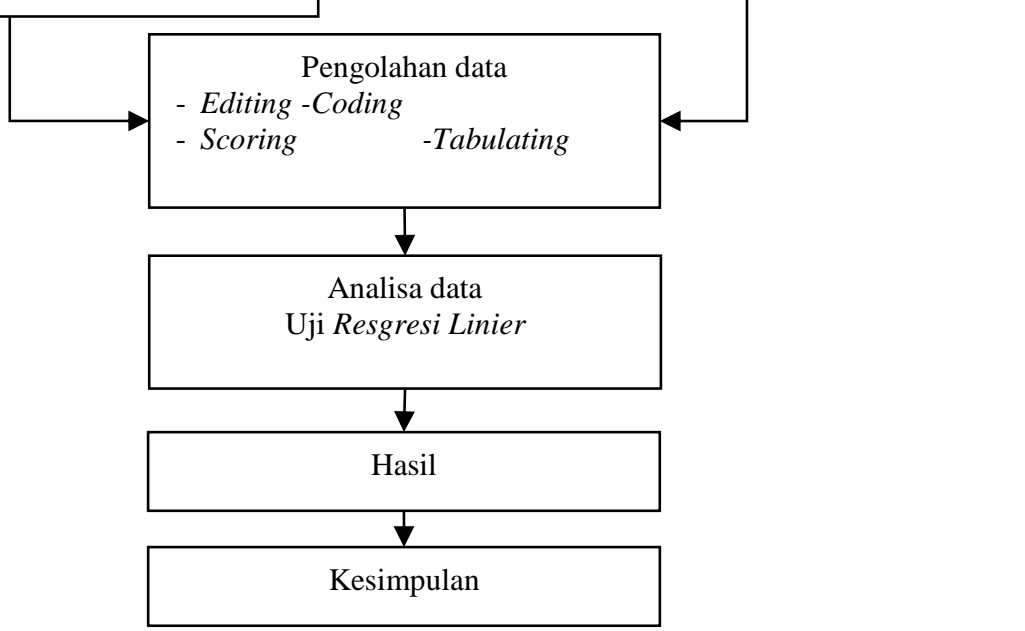




\section{METODE PENELITIAN}

\section{Desain Penelitian}

Jenis penelitian menurut pendekatannya adalah penelitian observasional karena dalam pengumpulan data informasi dilakukan tanpa adanya intervensi atau perlakuan pada populasi. Rancang bangun dari penelitian ini adalah penelitian cross sectional. Pada rancang bangun cross sectional, variabel penelitian diukur hanya sekali saja (Supriyanto \& Djohan, 2011). Penelitian ini bersifat kuantitatif karena bertujuan untuk mengetahui pengaruh antar variabel yang diuji dengan menggunakan uji statistik.

\section{Populasi dan Sampel Penelitian.}

Populasi penelitian ini adalah pasien rawat inap di RSUD Pare Kabupaten Kediri.

\section{Metode Pengambilan Sampel}

Pengambilan sampel menggunakan stratified random sampling. Asumsi penggunaan metode ini karena populasi penelitian adalah heterogen, terdiri atas beberapa stratum dimana tiap stratum sifatnya homogen (Supriyanto \& Djohan, 2011). Besar sampel penelitian adalah 99 sampel.

\section{Waktu dan Tempat Penelitian}

Obyek Penelitian diadakan di Rumah Sakit Umum Daerah Pare Kabupaten Kediri, selama 7 Bulan yang akan dimulai bulan Januari - Juli 2018

\section{Variabel Penelitian, Cara Pengukuran dan Definisi Operasional}

\section{Variabel Penelitian}

Variabel bebas dalam dalam penelitian ini adalah kepuasan pada kualitas layanan, sedangkan variabel terikat adalah niat pasien untuk melakukan DAMA (Discharge Against Medical Advice).

\section{Cara Pengukuran dan Definisi Operasional}

\begin{tabular}{|c|c|c|c|c|c|}
\hline $\begin{array}{l}\mathbf{N} \\
\mathbf{0}\end{array}$ & Variabel & $\begin{array}{c}\text { Sub } \\
\text { Variabel }\end{array}$ & $\begin{array}{c}\text { Definisi Operasional dan } \\
\text { Indikator }\end{array}$ & $\begin{array}{c}\text { Cara Mengukur dan Alat } \\
\text { Ukur }\end{array}$ & Skala Data \\
\hline $\begin{array}{l}1 \\
.\end{array}$ & $\begin{array}{l}\text { Kualitas } \\
\text { Interaksi }\end{array}$ & & $\begin{array}{l}\text { Kualitas yang berhubungan erat } \\
\text { dengan bagaimana proses layanan } \\
\text { itu disampaikan yaitu dilihat dari } \\
\text { proses interaksi staf penyedia } \\
\text { layanan terhadap pasiennya. Sub } \\
\text { variabel yang ada dalam kualitas } \\
\text { interaksi antara lain : } \\
\text { 1. Sikap } \\
\text { 2. Perilaku } \\
\text { 3. Keahlian }\end{array}$ & $\begin{array}{l}\text { Menggunakan kuesioner. } \\
\text { Menghitung nilai variabel } \\
\text { kemudian dikategorikan ke } \\
\text { dalam kelompok nilai yang } \\
\text { telah ditetapkan. }\end{array}$ & \\
\hline $\mathrm{a}$ & & $\begin{array}{l}\text { Sikap } \\
\text { Dokter }\end{array}$ & $\begin{array}{l}\text { Pendapat pasien tentang } \\
\text { kepribadian yang dimiliki oleh }\end{array}$ & $\begin{array}{l}\text { Kuesioner dengan } 3 \text { pertanyaan } \\
\text { untuk masing-masing pilihan }\end{array}$ & Interval \\
\hline
\end{tabular}




\begin{tabular}{|c|c|c|c|c|c|}
\hline $\begin{array}{l}\mathbf{N} \\
\mathbf{o}\end{array}$ & Variabel & $\begin{array}{c}\text { Sub } \\
\text { Variabel }\end{array}$ & $\begin{array}{l}\text { Definisi Operasional dan } \\
\text { Indikator }\end{array}$ & $\begin{array}{c}\text { Cara Mengukur dan Alat } \\
\text { Ukur }\end{array}$ & Skala Data \\
\hline & & & $\begin{aligned} \text { dokter yang menunjukkan } \\
\text { keramahan terhadap pasien. } \\
\text { 1. }\end{aligned}$ & $\begin{array}{l}\text { jawaban dengan penilaian yaitu } \\
: \\
1 \text { = Sangat Tidak Puas } \\
2=\text { Tidak Puas } \\
3=\text { Puas } \\
4=\text { Sangat Puas }\end{array}$ & \\
\hline $\mathrm{b}$ & & $\begin{array}{l}\text { Sikap } \\
\text { Perawat }\end{array}$ & 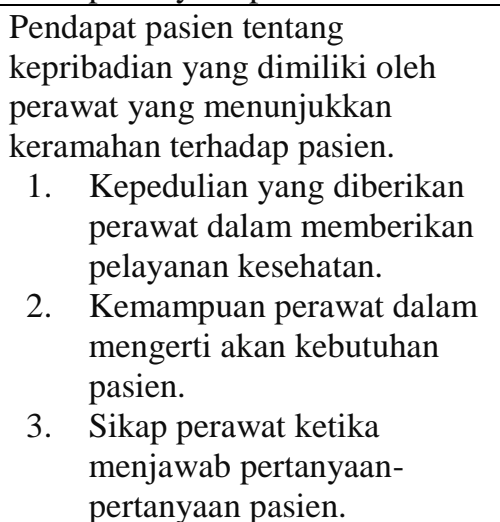 & $\begin{array}{l}\text { Kuesioner dengan } 3 \text { pertanyaan } \\
\text { untuk masing-masing pilihan } \\
\text { jawaban dengan penilaian yaitu } \\
: \\
1=\text { Sangat Tidak Puas } \\
2=\text { Tidak Puas } \\
3=\text { Puas } \\
4=\text { Sangat Puas }\end{array}$ & Interval \\
\hline c & & $\begin{array}{l}\text { Perilaku } \\
\text { Dokter }\end{array}$ & $\begin{array}{l}\text { Pendapat pasien tentang kemauan } \\
\text { dokter untuk melayani kebutuhan } \\
\text { pasien. } \\
\text { 1. Perilaku dokter dan perawat } \\
\text { dalam membantu pasien } \\
\text { untuk mendapat semua } \\
\text { rawat inap yang dibutuhkan. } \\
\text { 2. Perilaku dokter dan perawat } \\
\text { dalam membuat keputusan } \\
\text { yang tepat saat dibutuhkan. } \\
\text { 3. Ketepatan waktu pelayanan } \\
\text { yang diberikan dokter dan } \\
\text { perawat. } \\
\text { 4. Perilaku dokter dalam } \\
\text { mendengarkan keluhan } \\
\text { pasien. }\end{array}$ & $\begin{array}{l}\text { Kuesioner dengan } 4 \text { pertanyaan } \\
\text { untuk masing-masing pilihan } \\
\text { jawaban dengan penilaian yaitu } \\
: \\
1=\text { Sangat Tidak Puas } \\
2=\text { Tidak Puas } \\
3=\text { Puas } \\
4=\text { Sangat Puas }\end{array}$ & Interval \\
\hline $\mathrm{d}$ & & $\begin{array}{l}\text { Perilaku } \\
\text { Perawat }\end{array}$ & $\begin{array}{l}\text { Pendapat pasien tentang kemauan } \\
\text { perawat untuk melayani } \\
\text { kebutuhan pasien. } \\
\text { 1. } \\
\text { Ketanggapan perawat dalam } \\
\text { mengambil tindakan sesuai } \\
\text { kondisi pasien. } \\
\text { 2. Kecepatan perawat dalam } \\
\text { merespon kebutuhan pasien. } \\
\text { 3. Perilaku perawat dalam } \\
\text { mendengar keluhan pasien }\end{array}$ & $\begin{array}{l}\text { Kuesioner dengan } 3 \text { pertanyaan } \\
\text { untuk masing-masing pilihan } \\
\text { jawaban dengan penilaian yaitu } \\
: \\
1=\text { Sangat Tidak Puas } \\
2=\text { Tidak Puas } \\
3=\text { Puas } \\
4=\text { Sangat Puas }\end{array}$ & Interval \\
\hline $\mathrm{e}$ & & $\begin{array}{l}\text { Keahlian } \\
\text { Dokter }\end{array}$ & $\begin{array}{l}\text { Pendapat pasien tentang } \\
\text { kemampuan dokter dalam } \\
\text { melaksanakan pekerjaannya. } \\
\text { 1. } \begin{array}{l}\text { Keahlian dokter dalam } \\
\text { melakukan pemeriksaan. }\end{array}\end{array}$ & $\begin{array}{l}\text { Kuesioner dengan } 4 \text { pertanyaan } \\
\text { untuk masing-masing pilihan } \\
\text { jawaban dengan penilaian yaitu } \\
: \\
1 \text { = Sangat Tidak Puas } \\
2 \text { = Tidak Puas }\end{array}$ & Interval \\
\hline
\end{tabular}




\begin{tabular}{|c|c|c|c|c|c|}
\hline $\begin{array}{l}\mathbf{N} \\
\mathbf{o}\end{array}$ & Variabel & $\begin{array}{c}\text { Sub } \\
\text { Variabel }\end{array}$ & $\begin{array}{l}\text { Definisi Operasional dan } \\
\text { Indikator }\end{array}$ & $\begin{array}{c}\text { Cara Mengukur dan Alat } \\
\text { Ukur }\end{array}$ & Skala Data \\
\hline & & & $\begin{array}{ll}\text { 2. } & \begin{array}{l}\text { Kemudahan bahasa untuk } \\
\text { dimengerti yang digunakan } \\
\text { dokter dalam memberikan }\end{array} \\
\text { penjelasan. } \\
\text { 3. }\end{array}$ & $\begin{array}{l}3=\text { Puas } \\
4=\text { Sangat Puas }\end{array}$ & \\
\hline $\mathrm{ff}$ & & $\begin{array}{l}\text { Keahlian } \\
\text { Perawat }\end{array}$ & $\begin{array}{ll}\text { Pendapat pasien tentang } \\
\text { kemampuan perawat dalam } \\
\text { melaksanakan pekerjaannya. } \\
\text { 1. } & \text { Kemampuan perawat dalam } \\
& \text { memahami pekerjaan } \\
& \text { mereka. } \\
\text { 2. } & \text { Kemampuan perawat dalam } \\
\text { merawat pasien. } \\
\text { 3. } \\
\text { Kemudahan bahasa untuk } \\
\text { dimengerti yang digunakan } \\
\text { perawat dalam memberikan } \\
\text { informasi. } \\
\text { 4. } \begin{array}{l}\text { Kesesuaian tindakan yang } \\
\text { diberikan oleh perawat }\end{array}\end{array}$ & $\begin{array}{l}\text { Kuesioner dengan } 4 \text { pertanyaan } \\
\text { untuk masing-masing pilihan } \\
\text { jawaban dengan penilaian yaitu } \\
: \\
1=\text { Sangat Tidak Puas } \\
2=\text { Tidak Puas } \\
3=\text { Puas } \\
4=\text { Sangat Puas }\end{array}$ & Interval \\
\hline 2 & $\begin{array}{l}\text { Kualitas } \\
\text { Lingkunga } \\
\text { n Fisik }\end{array}$ & & $\begin{array}{l}\text { Kualitas yang ada di dalam } \\
\text { lingkungan dimana proses } \\
\text { pelayanan itu terjadi. Sub variabel } \\
\text { yang ada dalam kualitas } \\
\text { lingkungan fisik antara lain : } \\
\text { 1. Kondisi lingkungan } \\
\text { 2. Desain Ruangan }\end{array}$ & $\begin{array}{l}\text { Menggunakan kuesioner. } \\
\text { Menghitung nilai variabel } \\
\text { kemudian dikategorikan ke } \\
\text { dalam kelompok nilai yang } \\
\text { telah ditetapkan. }\end{array}$ & \\
\hline $\mathrm{a}$ & & $\begin{array}{l}\text { Kondisi } \\
\text { Ruangan }\end{array}$ & $\begin{array}{l}\text { Pendapat pasien tentang suatu } \\
\text { kondisi yang dapat memberikan } \\
\text { kenyamanan yang berkenaan } \\
\text { dengan aspek nonvisual. } \\
\text { 1. Kondisi toilet di ruang rawat } \\
\text { inap. } \\
\text { 2. Kondisi fisik ruang tunggu } \\
\text { rawat inap. } \\
\text { 3. Kebersihan ruang rawat } \\
\text { inap. } \\
\text { 4. Sarana dan prasarana } \\
\text { (tempat tidur, AC, dsb) yang } \\
\text { ada didalam ruang rawat } \\
\text { inap. } \\
\text { 5. Suasana/ ketenangan di } \\
\text { ruang tempat rawat inap }\end{array}$ & $\begin{array}{l}\text { Kuesioner dengan } 5 \text { pertanyaan } \\
\text { untuk masing-masing pilihan } \\
\text { jawaban dengan penilaian yaitu } \\
: \\
1=\text { Sangat Tidak Puas } \\
2=\text { Tidak Puas } \\
3=\text { Puas } \\
4=\text { Sangat Puas }\end{array}$ & Interval \\
\hline $\mathrm{b}$ & & $\begin{array}{l}\text { Desain } \\
\text { Ruangan }\end{array}$ & $\begin{array}{l}\text { Pendapat pasien tentang berkaitan } \\
\text { dengan tata letak atau arsitektur } \\
\text { ruangan. } \\
\text { 1. Tata letak ruang pemberian } \\
\text { pelayanan rawat inap. } \\
\text { 2. Warna dan mebel yang } \\
\text { digunakan di dalam ruang } \\
\text { rawat inap. }\end{array}$ & $\begin{array}{l}\text { Kuesioner dengan } 3 \text { pertanyaan } \\
\text { untuk masing-masing pilihan } \\
\text { jawaban dengan penilaian yaitu } \\
: \\
1=\text { Sangat Tidak Puas } \\
2=\text { Tidak Puas } \\
3=\text { Puas } \\
4=\text { Sangat Puas }\end{array}$ & Interval \\
\hline
\end{tabular}




\begin{tabular}{|c|c|c|c|c|c|}
\hline $\begin{array}{l}\mathbf{N} \\
\mathbf{o}\end{array}$ & Variabel & $\begin{array}{c}\text { Sub } \\
\text { Variabel }\end{array}$ & $\begin{array}{c}\text { Definisi Operasional dan } \\
\text { Indikator }\end{array}$ & $\begin{array}{c}\text { Cara Mengukur dan Alat } \\
\text { Ukur }\end{array}$ & Skala Data \\
\hline & & & $\begin{array}{l}\text { 3. } \\
\text { Kesesuaian tata letak } \\
\text { peralatan kesehatan di ruang } \\
\text { rawat inap }\end{array}$ & & \\
\hline 3 & $\begin{array}{l}\text { Kualitas } \\
\text { Hasil }\end{array}$ & & $\begin{array}{l}\text { Pendapat pasien tentang apa yang } \\
\text { pasien dapatkan ketika proses } \\
\text { pelayanan dan interaksi-nteraksi } \\
\text { antarpasien dengan penyedia } \\
\text { layanan selesai. }\end{array}$ & $\begin{array}{l}\text { Menggunakan kuesioner. } \\
\text { Menghitung nilai variabel } \\
\text { kemudian dikategorikan ke } \\
\text { dalam kelompok nilai yang } \\
\text { telah ditetapkan. }\end{array}$ & \\
\hline $\mathrm{a}$ & & Kesan & $\begin{array}{l}\text { Pendapat pasien tentang apa yang } \\
\text { pasien dapatkan ketika proses } \\
\text { pelayanan dan interaksi-nteraksi } \\
\text { antarpasien dengan penyedia } \\
\text { layanan selesai. } \\
\text { 4. Kepuasan pelayanan di } \\
\text { ruangrawat inap. } \\
\text { 5. Kepuasan pada upaya yang } \\
\text { dilakukan petugas di ruang } \\
\text { rawat inap dalam } \\
\text { memberikan pelayanan. } \\
\text { 6. Kesesuaian pelayanan yang } \\
\text { diberikan dengan kebutuhan } \\
\text { pasien. } \\
\text { 7. Perkembangan kondisi yang } \\
\text { Anda rasakan setelah } \\
\text { mendapatkan rawat inap }\end{array}$ & $\begin{array}{l}\text { Kuesioner dengan } 3 \text { pertanyaan } \\
\text { untuk masing-masing pilihan } \\
\text { jawaban dengan penilaian yaitu } \\
: \\
1=\text { Sangat Tidak Puas } \\
2=\text { Tidak Puas } \\
3=\text { Puas } \\
4=\text { Sangat Puas }\end{array}$ & Interval \\
\hline 4 & $\begin{array}{l}\text { Niat } \\
\text { DAMA } \\
\text { (Discharge } \\
\text { Against } \\
\text { Medical } \\
\text { Advice) }\end{array}$ & & $\begin{array}{l}\text { Niat pasien untuk meninggalkan } \\
\text { rumah sakit sebelum dokter yang } \\
\text { merawat menyarankan untuk } \\
\text { pulang. } \\
\text { 1. Memberitahu staf niat bahwa } \\
\text { ingin meninggalkan rumah } \\
\text { sakit. } \\
\text { 2. Niat untuk berpindah rumah } \\
\text { sakit yang memiliki kualitas } \\
\text { pelayanan rawat inap lebih } \\
\text { baik. } \\
\text { 3. Berpikir untuk berpindah } \\
\text { rumah sakit atau pulang } \\
\text { sesegera mungkin atas } \\
\text { keinginan sendiri. }\end{array}$ & $\begin{array}{l}\text { Kuesioner dengan } 3 \text { pertanyaan } \\
\text { untuk masing-masing pilihan } \\
\text { jawaban dengan penilaian yaitu } \\
: \\
1=\text { Sangat Tidak Setuju } \\
2=\text { Tidak Setuju } \\
3=\text { Setuju } \\
4=\text { Sangat Setuju }\end{array}$ & Interval \\
\hline
\end{tabular}

\section{Pengolahan dan Analisis Data}

\section{Statistik Deskriptif.}

Statistik deskriptif akan memberikan gambaran data yang diperoleh dari nilai ratarata, standard deviasi, maksimum, minimum, sum, range, kurtosis dan skewness. Dalam penelitian ini dilakukan analisis statistik deskriptif terhadap kepuasan pasien pada kualitas layanan rawat inap dan niat pasien untuk melakukan DAMA. Deskripsi data penelitian meliputi deskripsi variabel-variabel, indikator beserta karakteristiknya. Selain itu, 
karakteristik responden meliputi umur, jenis kelamin, pendidikan, dan lainnya juga akan dianalisi secara deskriptif.

\section{Uji Regresi Linier.}

Data yang telah dikumpulkan akan dianalisis secara kuantitatif. Persepsi responden akan diukur menggunakan skala sehingga hasilnya berbentuk angka. Selanjutnya angka tersebut akan diolah dengan metode statistik. Pengolahan data akan dilakukan menggunakan regresi linier untuk melihat pengaruh variabel independen terhadap variabel dependen dengan melihat nilai $\mathrm{P}$ dan Beta untuk melihat besar pengaruh dan arah pengaruh antara variabel independen terhadap variabel dependen.

Analisis uji regresi linier tersebut dilakukan dengan memasukkan variabel kualitas interaksi, kualitas fisik dan kualitas hasil sebagai variabel bebas dan niat DAMA sebagai variabel terikat. Variabel dianggap berpengaruh signifikan jika memiliki nilai $\mathrm{P}<0,05$. Kemudian dilihat nilai Standardized Beta untuk melihat kuat dan arah pengaruh.

\section{HASIL DAN PEMBAHASAN}

\section{Pengaruh Kualitas Interaksi terhadap Niat untuk Pulang Paksa}

Kualitas interaksi yaitu kualitas yang berhubungan erat dengan bagaimana proses layanan itu disampaikan yaitu dilihat dari proses interaksi staf penyedia layanan terhadap pelanggannya (Gronroos, 2000). Dalam penelitian ini akan dibahas pengaruh kualitas interaksi dokter dan perawat terhadap niat pasien untuk pulang paksa. Hasil uji pengaruh dilakukan menggunakan uji regresi linier bivariate karena tujuan dari penelitian ini adalah untuk menganalisis pengaruh antara dua variabel.

\section{Pengaruh Kualitas Interaksi Dokter terhadap Niat untuk Pulang Paksa}

Hasil uji pengaruh variabel kualitas interaksi dokter terhadap niat pasien untuk pulang paksa dapat dilihat pada tabel berikut.

\section{Coefficients $^{\mathrm{a}}$}

\begin{tabular}{|l|r|r|r|r|r|}
\hline \multirow{2}{*}{ Model } & \multicolumn{2}{|c|}{$\begin{array}{c}\text { Unstandardized } \\
\text { Coefficients }\end{array}$} & \multicolumn{1}{|c|}{$\begin{array}{c}\text { Standardized } \\
\text { Coefficients }\end{array}$} & \multirow{2}{*}{$\mathrm{t}$} & \multirow{2}{*}{ Sig. } \\
\cline { 2 - 5 } & \multicolumn{1}{|c|}{$\mathrm{B}$} & Std. Error & \multicolumn{1}{c|}{ Beta } & \\
\hline $\begin{array}{l}1 \text { (Constant) } \\
\text { skor kualitas } \\
\text { si dokter }\end{array}$ & 11.691 & 2.015 & & 5.803 & .000 \\
\hline
\end{tabular}

a. Dependent Variable:

Skor_Niat_Pulang_Paksa 
Berdasarkan tabel diatas dapat dilihat bahwa nilai signifikansi $(\mathrm{P}=0,018<\alpha=$ 0,05). Hasil ini menunjukkan bahwa semakin baik interaksi dokter kepada pasien maka semakin rendah niat pasien untuk pulang paksa. Peneliti selanjutnya ingin menganalisis indikator mana dari kualitas interaksi (sikap, perilaku dan keahlian) yang berpengaruh terhadap niat pasien untuk pulang paksa. Hasil tersebut dapat dilihat sebagai berikut.

\section{a. Sikap Dokter}

Sikap dokter menunjukkan kepribadian yang dimiliki oleh dokter yang menunjukkan keramahan terhadap pasien. Hasil uji pengaruh sikap dokter terhadap niat pasien pulang paksa adalah sebagai berikut.

Coefficients $^{\mathbf{a}}$

\begin{tabular}{|l|r|r|r|r|r|}
\hline \multirow{2}{*}{ Model } & \multicolumn{2}{|c|}{$\begin{array}{c}\text { Unstandardized } \\
\text { Coefficients }\end{array}$} & $\begin{array}{c}\text { Standardized } \\
\text { Coefficients }\end{array}$ & \multirow{2}{*}{$\mathrm{T}$} & \multirow{2}{*}{ Sig. } \\
\cline { 2 - 4 } & \multicolumn{1}{|c|}{$\mathrm{B}$} & Std. Error & \multicolumn{1}{c|}{ Beta } & \\
\hline 1 (Constant) \\
$\begin{array}{l}\text { Total Skor Sikap } \\
\text { Dokter }\end{array}$ & -.467 & 1.556 & & 4.800 & .000 \\
\hline
\end{tabular}

a. Dependent Variable:

\section{Skor_Niat_Pulang_Paksa}

Berdasarkan tabel diatas dapat dilihat bahwa nilai signifikansi $(\mathrm{P}=0,694>\alpha$ $=0,05)$. Dengan demikian sikap dokter tidak berpengaruh terhadap niat pasien untuk pulang paksa di RSUD Pare Kabupaten Kediri.

\section{b. Perilaku Dokter}

Perilaku di sini dimaksudkan dengan sifat yang baik dari dokter serta kemauan untuk melayani pasien..

\section{Coefficients $^{\mathbf{a}}$}

\begin{tabular}{|l|r|r|r|r|r|}
\hline \multirow{2}{*}{ Model } & \multicolumn{2}{|c|}{$\begin{array}{c}\text { Unstandardized } \\
\text { Coefficients }\end{array}$} & $\begin{array}{c}\text { Standardize } \\
\mathrm{d} \\
\text { Coefficients }\end{array}$ & \multirow{2}{*}{$\mathrm{t}$} & \multirow{2}{*}{ Sig. } \\
\cline { 2 - 5 } & \multicolumn{1}{|c|}{$\mathrm{B}$} & Std. Error & Beta & \\
\hline $\begin{array}{l}\text { (Constant) } \\
1 \text { Total Skor Perilaku } \\
\text { Dokter }\end{array}$ & 12.056 & 1.655 & & 7.282 & .000 \\
\hline
\end{tabular}

a. Dependent Variable:

Skor_Niat_Pulang_Paksa 
Berdasarkan tabel diatas dapat dilihat bahwa nilai signifikansi $(\mathrm{P}=0,002<\alpha$ $=0,05)$. Hasil ini menunjukkan bahwa semakin baik perilaku dokter kepada pasien maka semakin rendah niat pasien untuk pulang paksa.

\section{c. Keahlian Dokter}

Keahlian dokter diartikan sebagai kemampuan dokter dalam melaksanakan pekerjaannya. Contohnya, dokter tahu akan pekerjaannya dan memiliki pengetahuan yang bagus serta keahlian dalam memberikan pertolongan medis kepada pasien dengan baik.

\section{Coefficients $^{\mathbf{a}}$}

\begin{tabular}{|l|r|r|r|r|r|}
\hline \multirow{2}{*}{ Model } & \multicolumn{2}{|c|}{$\begin{array}{c}\text { Unstandardized } \\
\text { Coefficients }\end{array}$} & $\begin{array}{c}\text { Standardized } \\
\text { Coefficients }\end{array}$ & \multirow{2}{*}{$\mathrm{T}$} & \multirow{2}{*}{ Sig. } \\
\cline { 2 - 5 } & \multicolumn{1}{|c|}{$\mathrm{B}$} & Std. Error & \multicolumn{1}{c|}{ Beta } & \\
\hline 1 (Constant) & 10.927 & 1.820 & & 6.002 & .000 \\
$\begin{array}{l}\text { Total Skor Keahlian } \\
\text { Dokter }\end{array}$ & -.322 & .143 & -.223 & -2.249 & .027 \\
\hline
\end{tabular}

a. Dependent Variable:

Skor_Niat_Pulang_Paksa

Berdasarkan tabel diatas dapat dilihat bahwa nilai signifikansi $(\mathrm{P}=0,027<\alpha$ $=0,05)$. Hasil ini menunjukkan bahwa semakin baik keahlian dokter kepada pasien maka semakin rendah niat pasien untuk pulang paksa.

\section{Pengaruh Kualitas Interaksi Perawat terhadap Niat untuk Pulang Paksa}

Hasil uji pengaruh variabel kualitas interaksi perawat terhadap niat pasien untuk pulang paksa dapat dilihat pada tabel berikut.

\section{Coefficients $^{\mathrm{a}}$}

\begin{tabular}{|c|r|r|r|r|r|}
\hline \multirow{2}{*}{ Model } & \multicolumn{2}{|c|}{$\begin{array}{c}\text { Unstandardized } \\
\text { Coefficients }\end{array}$} & $\begin{array}{c}\text { Standardized } \\
\text { Coefficients }\end{array}$ & \multirow{2}{*}{$\mathrm{t}$} & \multirow{2}{*}{ Sig. } \\
\cline { 2 - 5 } & \multicolumn{1}{|c|}{$\mathrm{B}$} & Std. Error & \multicolumn{1}{c|}{ Beta } & \\
\hline $1 \quad \begin{array}{l}\text { (Constant) } \\
\begin{array}{l}\text { Total skor kualitas } \\
\text { interaksi perawat }\end{array}\end{array}$ & -.105 & 1.945 & & 5.602 & .000 \\
\hline
\end{tabular}

a. Dependent Variable: Skor_Niat_Pulang_Paksa

Berdasarkan tabel diatas dapat dilihat bahwa nilai signifikansi $(\mathrm{P}=0,040<\alpha=$ 0,05). Hasil ini menunjukkan bahwa semakin baik interaksi perawat kepada pasien maka semakin rendah niat pasien untuk pulang paksa. Peneliti selanjutnya ingin menganalisis indikator mana dari kualitas interaksi perawat (sikap, perilaku dan keahlian) yang 
berpengaruh terhadap niat pasien untuk pulang paksa. Hasil tersebut dapat dilihat sebagai berikut.

\section{a. Sikap Perawat}

Hasil uji pengaruh sikap perawat terhadap niat pasien pulang paksa adalah sebagai berikut.

\section{Coefficients $^{\mathrm{a}}$}

\begin{tabular}{|l|r|r|r|r|r|}
\hline \multirow{2}{*}{ Model } & \multicolumn{2}{|c|}{$\begin{array}{c}\text { Unstandardized } \\
\text { Coefficients }\end{array}$} & $\begin{array}{c}\text { Standardized } \\
\text { Coefficients }\end{array}$ & \multirow{2}{*}{$\mathrm{t}$} & \multirow{2}{*}{ Sig. } \\
\cline { 2 - 5 } & \multicolumn{1}{|c|}{$\mathrm{B}$} & Std. Error & \multicolumn{1}{c|}{ Beta } & & \\
\hline 1 (Constant) & 9.139 & 1.699 & & 5.379 & .000 \\
$\begin{array}{l}\text { Total Skor Sikap } \\
\text { Perawat }\end{array}$ & -.143 & .106 & -.136 & -1.352 & .179 \\
\hline
\end{tabular}

a. Dependent Variable:

Skor_Niat_Pulang_Paksa

Berdasarkan tabel diatas dapat dilihat bahwa nilai signifikansi $(P=0,179>\alpha$

$=0,05)$. Dengan demikian sikap perawat tidak berpengaruh terhadap niat pasien untuk pulang paksa di RSUD Pare Kabupaten Kediri.

\section{b. Perilaku Perawat}

Perilaku di sini dimaksudkan dengan sifat yang baik dari perawat serta kemauan untuk melayani pasien.

\section{Coefficients $^{\mathrm{a}}$}

\begin{tabular}{|l|r|r|r|r|r|}
\hline \multirow{2}{*}{ Model } & \multicolumn{2}{|c|}{$\begin{array}{c}\text { Unstandardized } \\
\text { Coefficients }\end{array}$} & $\begin{array}{c}\text { Standardized } \\
\text { Coefficients }\end{array}$ & \multirow{2}{*}{$\mathrm{T}$} & \multirow{2}{*}{ Sig. } \\
\cline { 2 - 4 } & \multicolumn{1}{c|}{$\mathrm{B}$} & Std. Error & \multicolumn{1}{c|}{ Beta } & & \\
\hline $1 \begin{array}{l}\text { 1 (Constant) } \\
\begin{array}{l}\text { Total Skor Perilaku } \\
\text { Perawat }\end{array}\end{array}$ & 10.799 & 1.712 & & 6.306 & .000 \\
\hline
\end{tabular}

a. Dependent Variable:

Skor_Niat_Pulang_Paksa

Berdasarkan tabel diatas dapat dilihat bahwa nilai signifikansi $(\mathrm{P}=0,023<\alpha$ $=0,05)$. Hasil ini menunjukkan bahwa semakin baik perilaku perawat kepada pasien maka semakin rendah niat pasien untuk pulang paksa.

c. Keahlian Perawat

Keahlian perawat diartikan sebagai kemampuan perawat dalam melaksanakan pekerjaannya. 


\section{Coefficients $^{\mathrm{a}}$}

\begin{tabular}{|l|r|r|r|r|r|}
\hline \multirow{2}{*}{ Model } & \multicolumn{2}{|c|}{$\begin{array}{c}\text { Unstandardized } \\
\text { Coefficients }\end{array}$} & $\begin{array}{c}\text { Standardized } \\
\text { Coefficients }\end{array}$ & \multirow{2}{*}{$\mathrm{t}$} & \multirow{2}{*}{ Sig. } \\
\cline { 2 - 5 } & \multicolumn{1}{|c|}{$\mathrm{B}$} & Std. Error & \multicolumn{1}{c|}{ Beta } & & \\
\hline (Constant) & 10.695 & 1.800 & & 5.943 & .000 \\
Total Skor Keahlian & -.302 & .141 & -.213 & -2.145 & .034 \\
\hline
\end{tabular}

a. Dependent Variable:

Skor_Niat_Pulang_Paksa

Berdasarkan tabel diatas dapat dilihat bahwa nilai signifikansi $(\mathrm{P}=0,034<\alpha$ $=0,05)$. Hasil ini menunjukkan bahwa semakin baik keahlian perawat kepada pasien maka semakin rendah niat pasien untuk pulang paksa.

\section{Pengaruh Kualitas Lingkungan Fisik terhadap Niat untuk Pulang Paksa}

Kualitas lingkungan fisik menurut Gronroos (2000) merupakan kualitas yang ada di dalam lingkungan dimana proses pelayanan itu terjadi. Dalam penelitian ini sub dimensi dari kualitas lingkungan fisik dibagi menjadi dua yaitu kondisi lingkungan dan desain. Hasil uji pengaruh kualitas lingkungan fisik terhadap niat pasien untuk pulang paksa adalah sebagai berikut.

\section{Coefficients $^{\mathrm{a}}$}

\begin{tabular}{|c|c|c|c|c|c|c|}
\hline & \multirow{2}{*}{ Model } & \multicolumn{2}{|c|}{$\begin{array}{c}\text { Unstandardized } \\
\text { Coefficients }\end{array}$} & \multirow{2}{*}{\begin{tabular}{|c|}
$\begin{array}{l}\text { Standardized } \\
\text { Coefficients }\end{array}$ \\
Beta
\end{tabular}} & \multirow[t]{2}{*}{$\mathrm{T}$} & \multirow{2}{*}{ Sig. } \\
\hline & & B & Std. Error & & & \\
\hline \multirow[t]{2}{*}{1} & (Constant) & 9.062 & 1.633 & & 5.550 & .000 \\
\hline & $\begin{array}{l}\text { Total skor kualitas } \\
\text { lingkungan }\end{array}$ & -.090 & .066 & -.137 & -1.360 & .177 \\
\hline
\end{tabular}

a. Dependent Variable: Skor_Niat_Pulang_Paksa

Berdasarkan tabel diatas dapat dilihat bahwa nilai signifikansi $(\mathrm{P}=0,177>\alpha=$ 0,05). Dengan demikian kualitas lingkungan tidak berpengaruh terhadap niat pasien untuk pulang paksa di RSUD Pare Kabupaten Kediri.

\section{Pengaruh Kualitas Hasil terhadap Niat untuk Pulang Paksa}

Kualitas hasil yaitu apa yang pelanggan dapatkan ketika proses produksi servis dan interaksi-nteraksi antar pelanggan dengan penyedia layanan selesai (Gronroos, 2000). Kualitas hasil digambarkan ke dalam tiga sub dimensi yaitu waktu tunggu, bentuk nyata dan valensi (ukuran tentang pengalaman yang didapat, bisa baik ataupun buruk). Hasil uji 
pengaruh variabel kualitas hasil terhadap niat pasien untuk pulang paksa adalah sebagai berikut.

\section{Coefficients $^{\mathrm{a}}$}

\begin{tabular}{|r|r|r|r|r|r|}
\hline \multirow{2}{*}{ Model } & \multicolumn{2}{|c|}{$\begin{array}{c}\text { Unstandardized } \\
\text { Coefficients }\end{array}$} & $\begin{array}{c}\text { Standardized } \\
\text { Coefficients }\end{array}$ & $\mathrm{t}$ & \multirow{2}{*}{ Sig. } \\
\cline { 2 - 6 } & \multicolumn{1}{c|}{$\mathrm{B}$} & Std. Error & \multicolumn{1}{c|}{ Beta } & & \\
\hline $1 \quad \begin{array}{l}\text { (Constant) } \\
\text { Total skor kualitas } \\
\text { hasil }\end{array}$ & 8.756 & 1.708 & & 5.125 & .000 \\
& -.151 & .135 & -.113 & -1.119 & .266 \\
\hline
\end{tabular}

a. Dependent Variable: Skor_Niat_Pulang_Paksa

Berdasarkan tabel diatas dapat dilihat bahwa nilai signifikansi $(P=0,266>\alpha$ $=0,05)$. Dengan demikian kualitas hasil tidak berpengaruh terhadap niat pasien untuk pulang paksa di RSUD Pare Kabupaten Kediri.

\section{SIMPULAN DAN SARAN}

\section{Kesimpulan}

Berdasarkan hasil penelitian dan pembahasan maka dapat kami simpulkan:

1. Hasil analisis data kualitas interaksi dokter diperoleh nilai signifikansi $(\mathrm{P}=0,018<\alpha$ $=0,05)$, dengan indikator sikap dokter nilai signifikansi $(P=0,694>\alpha=0,05)$; indikator perilaku dokter nilai signifikansi $(\mathrm{P}=0,002<\alpha=0,05)$; indikator keahlian dokter signifikansi $(\mathrm{P}=0,027<\alpha=0,05)$. kualitas interaksi dokter terhadap niat pasien untuk pulang paksa menunjukan bahwa semakin baik interaksi dokter kepada pasien maka semakin rendah niat pasien untuk pulang paksa.

2. Hasil analisi data kualitas interaksi perawat diperoleh nilai signifikansi $(P=0,040<\alpha$ $=0,05)$ dengan indikator sikap perawat nilai signifikansi $(P=0,179>\alpha=0,05)$, indikator perilaku perawat nilai signifikansi $(\mathrm{P}=0,023<\alpha=0,05)$, indikator keahlian perawat nilai signifikansi ( $\mathrm{P}=0,034<\alpha=0,05$. kualitas interaksi perawat terhadap niat pulang paksa menunjukan bahwa semakin baik interaksi perawat kepada pasien maka semakin rendah niat pasien untuk pulang paksa.

3. Hasil pengaruh kualitas lingkungan fisik terhadap niat pasien untuk pulang paksa dengan nilai signifikansi $(\mathrm{P}=0,177>\alpha=0,05)$, kualitas lingkungan fisik terhadap niat pasien untuk pulang paksa menunjukan bahwa kualitas lingkungan tidak berpengaruh terhadap niat pasien untuk pulang paksa. 
4. Hasil pengaruh kualitas hasil terhadap niat pasien untuk pulang paksa dengan nilai signifikansi $(\mathrm{P}=0,266>\alpha=0,05)$. kualitas hasil terhadap niat pulang paksa yang digambarkan tiga subdimensi yaitu waktu tunggu, bentuk nyata dan valensi menunjukan kualitas hasil tidak berpengaruh terhadap niat pasien untuk pulang paksa.

Atas dasar hasil penelitain tersebut maka kualitas interaksi dokter dan karyawan dengan indikator sikap, perilaku dan keahlian perlu ditingkatkan sehingga dapat meningkatkan dan menjaga kualitas pelayanan kepada masyarakat khususnya pasien rawat inap di RSUD Pare Kab. Kediri.

\section{Saran}

1. Perlu mengadakan atau mengikut sertakan petugas dalam pelatihan sesuai dengan profesi untuk meningkatkan kemampuan dan ketrampilan pelayanan kesehatan yang berdampak pada meningkatkan ketanggapan pelayanan kepada pasien.

2 Meningkatkan courtesy yang dimiliki para contect personnelnya / karyawan sehingga pasien lebih tenang dan cepat sembuh.

3. Sampel penelitian dapat diperluas dengan mengambil dua atau lebih rumah sakit umum yang memberikan pelayanan asuransi Jamkesmas sebagai objek penelitian. Semakin banyak rumah sakit yang diambil sabagai objek penelitian semakin baik pula hasil penelitian yang diperoleh, mengingat penelitian ini hanya menggunakan satu rumah sakit sabagai objek penelitian.

\section{DAFTAR PUSTAKA}

Alfandre, D. (2009). "I'm going home" : discharges against medical advice. . Mayo Clin Proc , 255-260.

Brady, M. K., \& Cronin, J. J. (2001). Some New Thoughts on Conceptualizing Perceived Service Quality: A Hierarchical Approach. Journal of Marketing , 65 (3), 34-49.

Glasgow, J. M., Vaughn-Sarrazin, M., \& Kaboli, P. J. (2010). Leaving against medical advice (AMA): risk of 30-day mortality and hospital readmission. General med, 926-929.

Gronroos, C. (2000). Service Management and Marketing: A Customer Relationship Management Approach (2nd Edition ed.). Chichester: John Wiley \& Sons, Ltd.

Indonesia, P. R. (2009). Undang-Undang Republik Indonesia Nomor 44 tahun 2009 Tentang Rumah Sakit. Jakarta: Republik Indonesia. 
Lekas, H. M., Alfandre, D., Gordon, P., Hrwood, K., \& Yin, M. T. (2016). The role of patient-provider interactions : Using an accounts framework to explain hospital discharge against medical advice. Elsevier, 106-113.

Macrohon, B. (2012). Pediatrician's perspectives on discharge against medical advice (DAMA) among pediatric patients: Aqualitative study. BMC Pediatr , 75.

Mohseni, M., Alikhani, M., Tourani, S., Azami-Aghdash, S., Royani, S., \& Moradi-Joo, M. (2015). Rate and causes of discharge against medical advice in Iranian hospitals : A Systematic review and meta-analysis. Iran J. Public Health, 902912.

Parasuraman, A., Zeithaml, V. A., \& Berry, L. L. (1985). Aconceptual Model of Sevice Quality and Its Implications for Future Research. Journal of Marketing , 49, 4150 .

Pahlevi, W. (2009). Analisis Pelayanan Pasien Rawat Inap di Unit Admisi RSUD Budhi Asih Jakarta Timur Tahun 2009. Jakarta: Universitas Indonesia.

Satriyono, G., \& Ruhamak, M. D. (2017). Analisis Kesenjangan Antara Ekspektasi Konsumen Terhadap Persepsi Jasa Pelayanan (Studi Kasus Pada Bengkel Cat Dan Las Mobil Warna Indah Di Kediri). EkoNiKa Jurnal Ekonomi Universitas Kadiri, 2(2), 127-141. https://doi.org/http://dx.doi.org/10.30737/ekonika.v2i2.39

Southern, W. N., Nahvi, S., \& Arnsten, J. H. (2012). Increased risk of mortality and readmission among patients discharged against medical advice. Am. J. Med, 393.

Supriyanto, S. \& Djohan, A. J., 2011. Metodologi Riset Bisnis dan Kesehatan. Banjarmasin: PT. Grafika Wangi Kalimantan. 